Maccario, M., and Messis, C. P. (1969). Lancet, 2, 352.

Mayes, P. A., and Felts, J. M. (1967). Biochemical fournal, 103, 400.

Mirsky, I. A., Franzlau, A. N., Nelson, N., and Nelson, W. E. (1941). fournal of Clinical Endocrinology, 1, 307.

Morgan, C. R., and Lazarow, A. (1963). Diabetes, 12, 115.

Poulton, E. P. (1918). Lancet, 1, 863 .

Pyke, D. A. (1969). Fournal of Clinical Pathology, 22, Suppl. No. 2, p. 57.

Salway, J. G. (1969). Clinica Chimica Acta, 25, 109.

Schwartz, T. B., and Apfelbaum, R. I. (1966). In Year Book of Endocrinology 1965-1966, ed. T. B. Schwartz, p. 165. Chicago, Year Book Medical Publishers.

Sheldon, J., and Taylor, K. W. (1965). fournal of Endocrinology, 33, 157.

Sølvsteen, P., Olsen, V. V., and Hansen, E. L. (1968). Acta Medica Scandinavica, 184, 83.

Soskin, S., and Levine, R. (1940). American fournal of Physiology, 129, 782. Spenney, J. G., Eure, C. A., and Kreisberg, R. A. (1969). Diabetes, 18, 107.
Stadelmann, E. (1883). Archiv für experimentelle Pathologie und Pharmakologie, 17, 419.

Start, C., and Newsholme, E. A. (1968). Biochemical fournal, 109, 37P.

Sterky, G. C. G., Persson, B. E. H., and Larsson, Y. A. A. (1966). Diabetologia, 2, 14

Stern, I., and Shapiro, B. (1953). Fournal of Clinical Pathology, 6, 158.

Tulloch, J. A., and MacIntosh, D. (1961). Lancet, 2, 119.

Tyler, F. H. (1968). American Fournal of Medicine, 45, 485.

Watkins, P. J., and FitzGerald, M. G. (1968). Diabetes, 17, 398.

Werk, E. E., Garber, S., and Sholiton, L. J. (1961). Metabolism, 10, 115.

Williamson, D. H., Mellanby, J., and Krebs, H. A. (1962). Biochemical fournal, 82,90 .

Willms, B., Böttcher, M., Wolters, V., Sakamoto, N., and Söling, H.-D. (1969). Diabetologia, 5, 88.

Zierler, K. L., and Rabinowitz, D. (1964). fournal of Clinical Investigation, 43, 950.

\title{
Effects of Large Doses of Colistin Sulphomethate Sodium on Renal Function
}

\author{
D. J. E. PRICE, ${ }^{*}$ F.R.C.S. ; D. I. GRAHAM, † M.B., B.CH.
}

British Medical fournal, 1970, 4, 525-527

\begin{abstract}
Cummary: High doses of colistin were used in the treat$\checkmark$ ment of severely ill patients with refractory klebsiella chest and urinary tract infections. At the same time renal function was monitored to determine possible nephrotoxicity. In all patients it produced acute renal failure and in some acute tubular necrosis. Though renal failure contributed to the final cause of death in some cases, in the majority death was due to the primary neurological illness.
\end{abstract}

\section{Introduction}

The nephrotoxicity of colistin has been a matter of controversy. In spite of reports of renal damage (Tallgren, Liewendahl, and Kuhlbäck, 1965; Elwood, Lucas, and Muehrcke, 1966), several authors have failed to find any such evidence (Yow, Tan, Shane, Schonfeld, and Abu-Nassar, 1961; Colley and Frankel, 1963; Halliday, 1967).

During a 10-month period in $196830 \%$ of patients in an intensive care unit had klebsiella chest infections and $12 \%$ had urinary tract infections. Eight patients developed klebsiella meningitis (Price and Sleigh, 1970), all of whom died despite appropriate antibiotic therapy. All the strains isolated were sensitive to colistin in vitro, but none of the patients with chest or urinary tract infections responded to colistin in standard dosage (4 mega units per day).

Though we were aware of the possible adverse effects of colistin on renal function, the failure to control the infection with conventional doses led us to increase the dosage sixfold to 26 mega units per day (10 mega units by intramuscular injection, 10 mega units by intravenous injection, and 6 mega units by aerosol inhalation). In the subsequent six-week period the incidence of klebsiella chest and urinary tract infections was halved.

\section{Patients and Investigations}

Fourteen patients aged 31 to 71 years (10 men and 4 women) were treated with high doses of colistin, each receiving 26 mega units per day. Four had a 15-day course, five between one and two weeks, and five less than a week. The mean length of treatment was $\mathbf{9 . 7}$ days. Five of these patients had cerebral abscesses, three had oerebral tumours, four had head injuries, and two had intracranial haemorrhage. Nine of the group were deeply unconscious and four required

\footnotetext{
* Senior Registrar, Department of Neurosurgery. t Lecturer in Neuropathology.
}

The Institute of Neurological Sciences, Glasgow. tracheostomy. Eight had klebsiella tracheobronchitis, one had klebsiella urinary tract infection, and five had both. During and after treatment eight patients died-one with a cerebral abscess, two with malignant tumours, three with head injuries, and two with intracranial haemorrhages. Six of the patients came to necropsy.

Sequential specimens of urine and sputum were examined bacteriologically and the urine was examined for casts. Serum and urine colistin levels, blood urea, serum creatinine, and creatinine clearance rates were determined at the onset of, during, and after treatment.

\section{Results}

Bacteriology.-The organism was eliminated from the sputum in 11 out of 13 patients within a week and from the uri.se of six out of six patients in three days.

Renal Function Tests at Onset of Treatment.-Some patients were dehydrated, but within 24 hours of intravenous fluid therapy none had a blood urea above $45 \mathrm{mg} . / 100 \mathrm{ml}$. or a serum creatinine above $1.4 \mathrm{mg} . / 100 \mathrm{ml}$.

Effects of Colistin on Renal Function.-In all patients a considerable fall in creatinine clearance and rises in both blood urea and serum creatinine levels were observed. Casts appeared in the urine of five patients during the course of treatment. In the six who survived the creatinine clearance rate, serum creatinine, and blood urea returned to within normal limits. On the basis of these findings the patients seemed to fall into two categories. Category 1 (Fig. 1) comprised four patients whose creatinine clearance rate returned to the lower limits of normal within an average of three weeks (19, 30,19 , and 20 days respectively. The graphs of Cases 1 and 4 show the expected rise in serum creatinine as the creatinine clearance rate falls. In Cases 2 and 3 this expected concurrent inverse relationship is not apparent at the time of the greatest reduction in creatinine clearance rate. This was presumably due to faulty collection of 24-hour urine specimens. Category 2 consisted of two patients whose creatinine clearance rate did not return to normal for about nine weeks (60 and 64 days respectively). Full information is available on only one patient (Case 5) (Fig. 2), though the trend was very similar in the second (Case 6 ).

In the eight patients who died during or shortly after treatment there was a similar fall in creatinine clearance rate and a rise in the blood urea and serum creatinine (see Table). In 
Creatinine Clearance Rate, Serwom Creatinine, and Blood Urea Leoels in the Eight Patients Who Died during or ofter Course of High-dosage Colistin

\begin{tabular}{|c|c|c|c|c|c|c|c|c|c|c|c|c|c|}
\hline & \multirow{2}{*}{ Cose } & \multicolumn{12}{|c|}{ Days from Start of Treatment } \\
\hline & & 1 & 2 & 4 & 6 & 8 & 10 & 12 & 14 & 16 & 18 & 20 & 22 \\
\hline $\begin{array}{l}\text { Creatinine } \\
\text { clearance } \\
\text { (mi./min.) }\end{array}$ & $\begin{array}{r}7 \\
8 \\
9 \\
10 \\
11 \\
12 \\
13 \\
14\end{array}$ & $\begin{array}{l}\overline{90} \\
\overline{-} \\
\bar{Z} \\
\overline{-}\end{array}$ & $\begin{array}{c}150 \\
58 \\
35 \\
10 \\
9 \\
16 \\
+\end{array}$ & $\begin{array}{r}77 \\
51 \\
14 \\
49 \\
10 \\
9 \\
18\end{array}$ & $\begin{array}{l}89 \\
64 \\
21 \\
+ \\
+ \\
+ \\
-\end{array}$ & $\begin{array}{l}77 \\
50 \\
28 \\
\\
0.04\end{array}$ & $\begin{array}{l}42 \\
52 \\
30 \\
\\
+\end{array}$ & $\begin{array}{l}43 \\
20 \\
-\end{array}$ & $\begin{array}{c}49 t \\
12 t \\
+\end{array}$ & $\begin{array}{r}65 \\
8\end{array}$ & $\overline{16}$ & 二 & $=$ \\
\hline $\begin{array}{l}\text { Serum } \\
\text { creatinine } \\
(\mathrm{mg} . / 100 \mathrm{ml} .)\end{array}$ & $\begin{array}{r}7 \\
8 \\
9 \\
10 \\
11 \\
12 \\
13 \\
14 \\
\end{array}$ & $\begin{array}{l}\overline{-} \\
\overline{0.7} \\
\overline{0.6} \\
0.7 \\
-\end{array}$ & $\begin{array}{c}1.2 \\
1.0 \\
1.4 \\
0.7 \\
1.0 \\
0.6 \\
0.9 \\
+\end{array}$ & \begin{tabular}{|l}
0.9 \\
0.9 \\
2.1 \\
2.6 \\
3.6 \\
2.6 \\
0.8
\end{tabular} & $\begin{array}{c}1.3 \\
0.9 \\
1.9 \\
+ \\
+ \\
+ \\
3.2\end{array}$ & $\begin{array}{l}1.6 \\
0.9 \\
1.6\end{array}$ & $\begin{array}{c}2.0 \\
0.9 \\
\\
+\end{array}$ & $\begin{array}{l}1.8 \\
1.2\end{array}$ & $\begin{array}{c}1.3+ \\
1.6 t \\
+\end{array}$ & $\begin{array}{l}1.4 \\
1.8\end{array}$ & $\overline{1 \cdot 2}$ & $\overline{1 \cdot 1}$ & $\overline{1.0}$ \\
\hline $\begin{array}{l}\text { Blood } \\
\text { urea } \\
\text { (ms. } / 100 \mathrm{ml} \text {.) }\end{array}$ & $\begin{array}{r}7 \\
8 \\
9 \\
10 \\
11 \\
12 \\
13 \\
14\end{array}$ & $\begin{array}{l}-14 \\
29 \\
17 \\
29 \\
23 \\
40 \\
36\end{array}$ & $\begin{array}{c}66 \\
63 \\
38 \\
21 \\
56 \\
29 \\
59 \\
+\end{array}$ & $\begin{array}{r}40 \\
37 \\
66 \\
52 \\
104 \\
62 \\
97\end{array}$ & $\begin{array}{c}47 \\
35 \\
57 \\
+ \\
+ \\
+ \\
128\end{array}$ & $\begin{array}{r}53 \\
30 \\
45 \\
\\
171\end{array}$ & $\begin{array}{l}79 \\
44 \\
58\end{array}$ & $\begin{array}{l}68 \\
47 \\
84\end{array}$ & $\begin{array}{c}55 t \\
50+ \\
+\end{array}$ & $\begin{array}{l}50 \\
61\end{array}$ & $\overline{58}$ & $\overline{50}$ & $\overline{40}$ \\
\hline
\end{tabular}

tEnd of Course of Treatment.

tDeath.

the two patients (Cases 7 and 8) who survived the full course of treatment the biochemical findings had started to return to normal before they died.

Colistin Levels.-The mean serum colistin levels during treatment ranged from 22 to $82 \mu \mathrm{g} . / \mathrm{ml}$. (mean $49 \mu \mathrm{g} . / \mathrm{ml}$ ). The mean urinary levels were very variable, ranging from 85 to $1,074 \mu \mathrm{g} . / \mathrm{ml}$., with a mean of $340 \mu \mathrm{g} . / \mathrm{ml}$. and a $95 \%$ confidence range of 278 to $405 \mu \mathrm{g} . / \mathrm{ml}$.

\section{Necropoy findings}

In the six patients on whom necropsy was carried out between 1 and 3 days after death, the only residual evidence of klebsiella infection was a solitary thick-walled lung abscess in one. No histological evidence of tracheobronchitis was found.
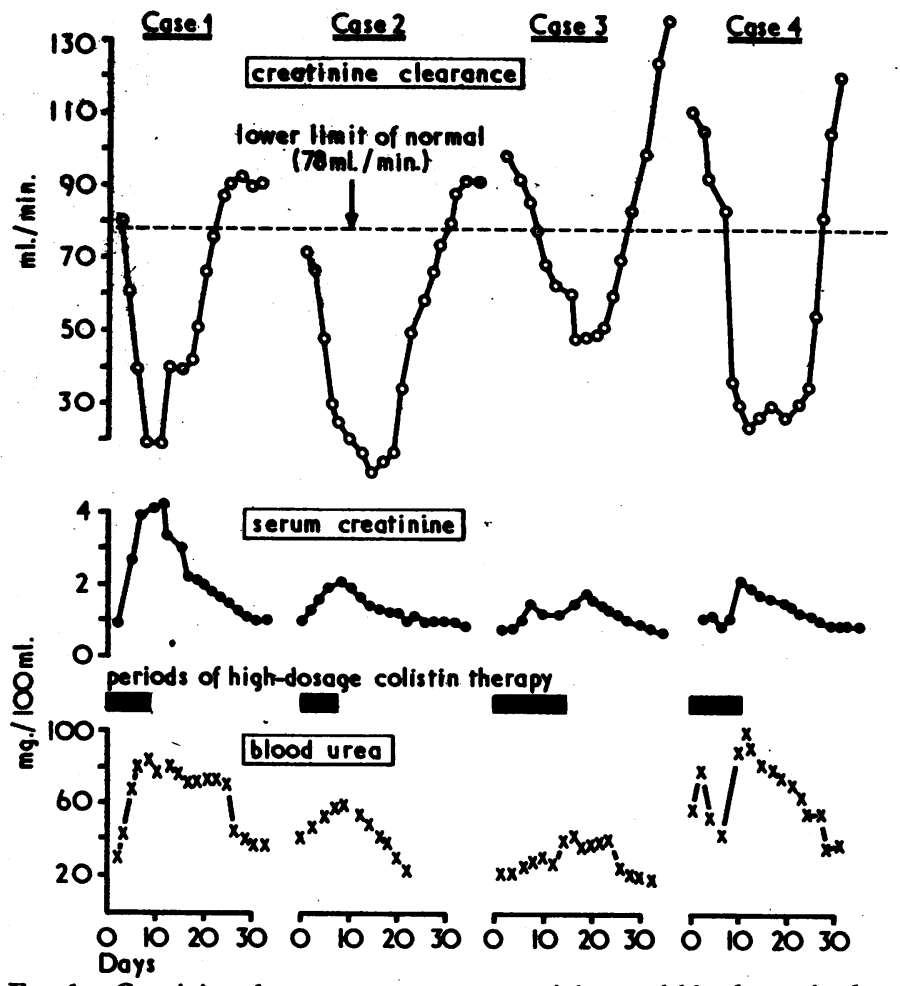

FIG. 1.- Creatinine clearance rate, serum creatinine, and blood urea in the four patients comprising category 1 in whom acute renal failure developed after starting high-dosage colistin therapy.
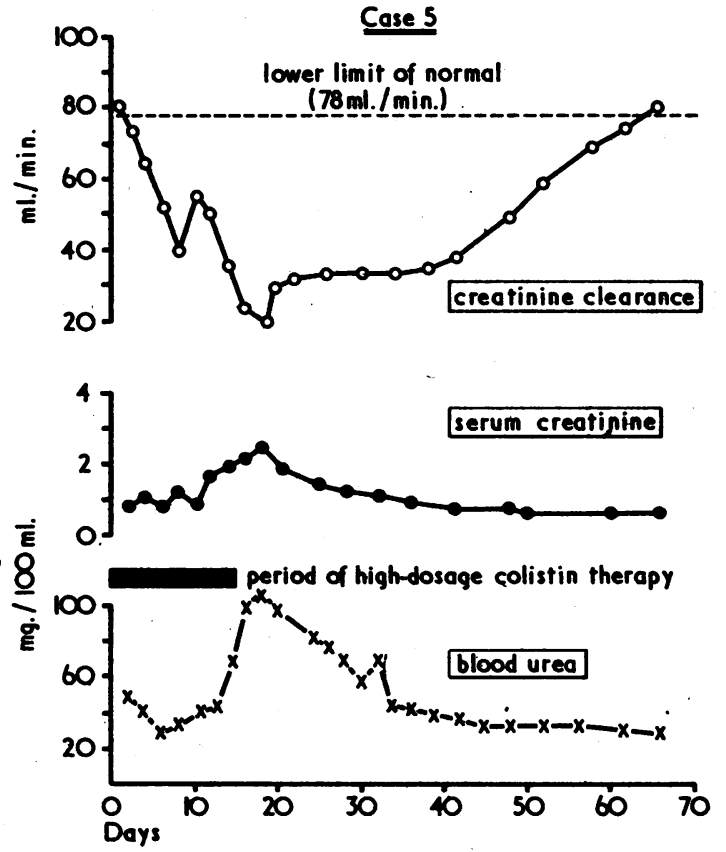

FIG. 2.-Creatinine clearance rate, serum creatinine, and blood urea in the category 2 patient who probably developed acute tubular necrosis after high-dosage colistin therapy.

In three (Cases 10, 11, and 13) the kidneys were uniformly enlarged (weight 200-260 g. each), the cut surfaces showing pallor of the cortex and congestion of the medulla. In two (Cases 12 and 14) they appeared normal and in one (Case 9) they were scarred from chronic pyelonephritis. Definite histological evidence of tubular necrosis was seen in five cases. This was shown by focal irregular dilatation of tubules, many of which contained granular casts, debris, and desquamated epithelial cells. Many tubules were denuded of epithelium or lined by flattened or regenerating cells showing mitotic activity (Figs. 3 and 4). In all instances the basement membrane was intact. The glomeruli were normal. Apart from hypertensive vascular disease in Cases 10 and 11 and scarring from chronic pyelonephritis in Case 9, no other abnormatities were seen, and in particular there was no histologicad evidence of acute inflammation. In the five cases showing acute tubular necrosis the juxuglomerular apparatus was entarged. In the sixth patient (Case 14) only degenerative changes in the tubular epithelium were scen. Though this patient hed

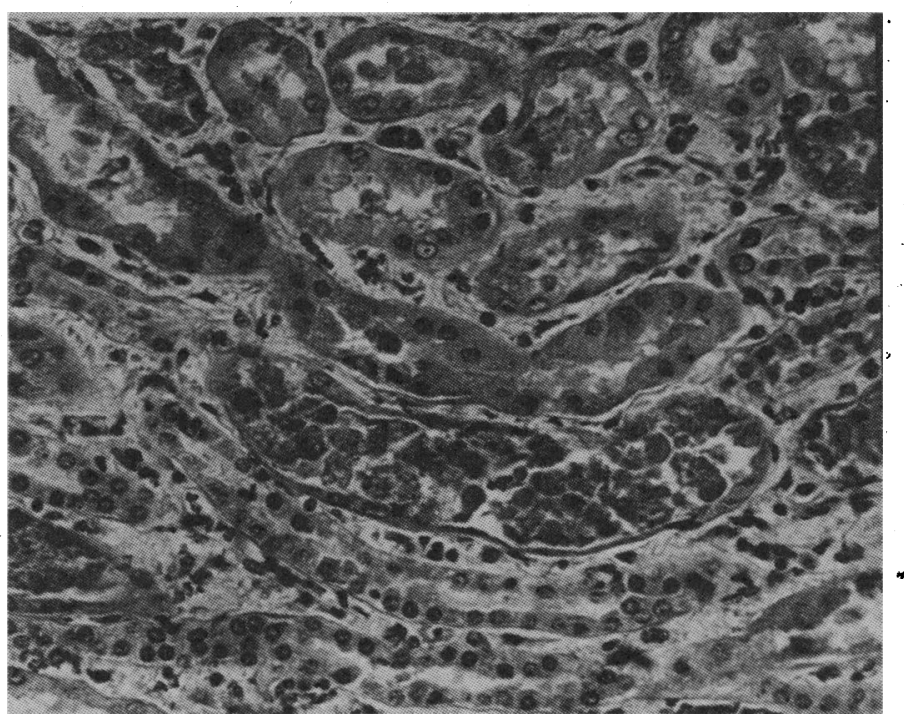

Fre. 3.-Kidney of Case 10 with fentures of acute tu bular necrosis. Some of the tubules contain granular casts, debris, and desquamated epithelium, and are lined by fiattened regenerating cells. (Haemalum and cosin. $\times 190$ ). 


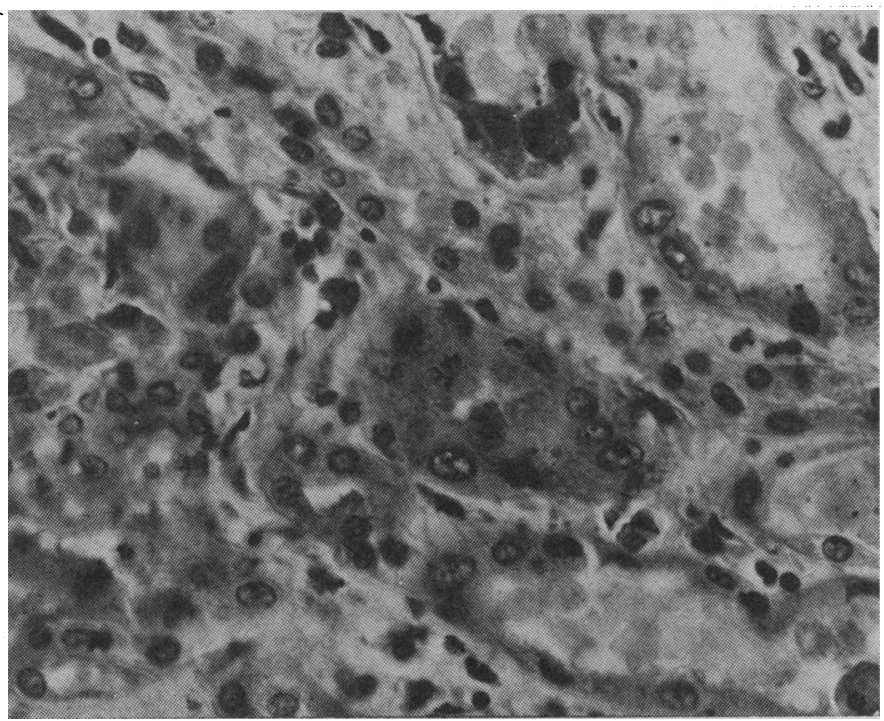

FIG. 4.-Kidney of Case 10, showing acute tubular necrosis with mitotic figure in regenerating tubular epithelium. (Haemalum and cosin. $\times 300$ ).

received only 52 mega units of colistin the histological appearances, in conjunction with the biochemical findings, are probably indicative of an early form of tubular necrosis.

\section{Discussion}

Sequential renal function tests were performed on eight patients who received the full course of treatment. In the six who survived there was a return to normal of the serum creatinine, blood urea, and creatinine clearance rates after varying periods. The time taken for the creatinine clearance rates to return to normal suggests that the patients in category $1 \mathrm{had}$ developed acute renal failure and that acute tubular necrosis had not supervened (Sevitt, 1959; Finckh, Jeremy, and Whyte, 1962), whereas the delayed return to normal of the creatinine clearance rates of the patients in category 2 indicates that they had developed acute tubular necrosis (Briggs, Kennedy, Young, Luke, and Gray, 1967). Even though data from the eight patients who died are necessarily incomplete, the abnormal biochemical findings had started to return to normal in the two who had completed the course of treatment (Cases 7 and 8). These two cases are included in the group of patients who came to necropsy, most of whom were found to have histological evidence of acute tubular necrosis.

In the past five years there have been several reports of reversible nephrotoxicity with antibiotic therapy. They include penicillin (Schrier, Bulger, and VanArsdel, 1966), methicillin (Brauninger and Remington, 1968), ampicillin (Caldwell, Martin, and Trigger, 1969), polymixin B sulphate and neomycin sulphate (Vinnicombe and Stamey, 1969), colistin sulphomethate sodium (Brumfitt, Black, and Williams, 1966; Caldwell et al., 1969; Vinnicombe and Stamey, 1969), pentoN-sulphomethyl polymyxin sodium (Caldwell et al., 1969; Vinnicombe and Stamey, 1969), and cephaloridine (Lawson, Macadam, Singh, Gavras, and Linton, 1970).

Many factors predispose to acute renal failure (Heptinstall, 1967; Brown et al., 1970). Though a single major contributing factor has not been identified in any of our patients, many were postoperatively severely ill and debilitated, with signifi- cant sepsis. These factors alone would be sufficient to lower the creatinine clearance rate but only in the cases comprising category 2 and in five of the six who died was treatment with high-dosage colistin a sufficient stimulus to precipitate acute tubular necrosis. No patient in the entire series was receiving other drugs with known toxic effects on the kidneys, and in all cases the blood pressure was maintained at normal levels. We would like to stress that while renal failure undoubtedly contributed to the final cause of death in some of our patients, in only one (Case 13) was it the actual cause of death, which in most instances was due to the primary neurological illness.

In the five cases whose kidneys at necropsy showed histological evidence of acute tubular necrosis there was obvious enlargement of the juxtaglomerular apparatus. This is of particular interest in view of the suggestion (Brown et al., 1970) that renin is concerned in the initiation of many different types of acute renal failure. It is possible, therefore, that in some way the increased dose of colistin initiated a cycle of events in our patients which produced reversible acute renal failure in some (category 1) and acute tubular necrosis in others (category 2 and necropsy cases).

We would conclude that, in common with other frequently used antibiotics, colistin is nephrotoxic, particularly when given to severely ill patients. In such cases it may precipitate either acute renal failure or acute tubular necrosis. In our opinion colistin may be used in the treatment of refractory klebsiella respiratory and urinary tract infections even in high dosage, provided renal function is carefully monitored. In all patients receiving high dosages of colistin there was a pronounced fall in the creatinine clearance, rate, which in our limited experience of six patients who survived fell to extremely low levels without precipitating fatal uraemia.

We would like to thank the physicians and surgeons of the Institute of Neurological Sciences, Glasgow, for allowing us to study patients under their care; and the technical staff of the chemical pathology laboratory, Killearn Hospital, for the biochemical estimations.

Requests for reprints should be addressed to Mr. D. J. E. Price, Division of Neurosurgery, Institute of Neurological Sciences, Killearn Hospital, Stirlingshire.

REFERENCES

Brauninger, G. E., and Remington, J. S. (1968). Fournal of the American

Medical Association, 203, 103.
Briggs, J. D. Kennedy, A. C., Young, L. N., Luke, R. G., and Gray, M. (1967). British Medical fournal, 3, 513.

Brown, J. J., et al. (1970). British Medical fournal, 1, 253.

Brumfitt, W., Black, M., and Williams, J. D. (1966). British fournal of Urology, 38, 495.

Caldwell, A. D. S., Martin, A. J., and Trigger, D. J. (1969). British fourmal of Pharmacology, 37, 283.

Colley, E. W., and Frankel, H. L. (1963). British Medical fournal, 2, 790. Elwood, C. M., Lucas, G. D., and Muehrcke, R. C. (1966). Archives of Internal Medicine, 118, 326.

Finckh, E. S., Jeremy, D., and Whyte, H. M. (1962). Quarterly fournal of Medicine, $31,429$.

Halliday, N. P. (1967). Clinical Trials fournal, 4, 771.

Heptinstall, R. H. (1967). Pathology of the Kidney. London, Churchill.

Lawson, D. H., Macadam, R. F., Singh, H., Gavras, H., and Linton, A. L. (1970). International Conference on Cephalosporins, Brighton.

Price, D. J. E., and Sleigh, J. D. (1970). In preparation.

Schrier, R. W., Bulger, R. J., and VanArsdel, P. P. (1966). Annals of Internal Medicine, 64, 116.

Sevitt, S. (1959). Lancet, 2, 135.

Tallgren, L. G., Liewrendahl, K., and Kuhlbäck, B. (1965). Acta Medica Scandinavica, 177, 717.

Vinnicombe, J., and Stamey, T. A. (1969). Investigative Urology, $6,505$.

Yow, E. M., Tan, E., Shane, L., Schonfeld, S., and Abu-Nassar, H. (1961). Archives of Internal Medicine, 108, 664. 